\title{
HUBUNGAN KECEMASAN DAN BEBAN KELUARGA DENGAN KEMAMPUAN ANGGOTA KELUARGA MERAWAT PASIEN PERILAKU KEKERASAN DI RUMAH SAKIT JIWA PROF. DR. SOEROJO MAGELANG
}

\author{
Indah Permatasari ${ }^{1}$, Ririn Isma Sundari ${ }^{2}$, Arni Nur Rahmawati ${ }^{3}$ \\ ${ }^{1}$ Mahasiswa Ilmu Keperawatan S1, STIKes Harapan Bangsa Purwokerto \\ ${ }^{2,3}$ Dosen Keperawatan S1, STIKes Harapan Bangsa Purwokerto \\ Email : indahxindah@gmail.com
}

\begin{abstract}
The number of peopel with mental disorders in Central Java 2012 is quite high. It is about 3.3009.300 people. This number is only from the diagnosed patients. One of them is mental disorder of violent behavior. The data obtained from RSJ Prof. Dr. Soerojo Magelang about this disorder reached 643 patients from May to October 2017. Violent behavior raises anxiety and burdens on families who care the people with violent behavior. The objective of this research was to find out the anxiety and family burden relationships with family members ability in caring violent behavior patients in RSJ Prof. Dr. Soerojo Magelang. This research used cross sectional approach with 52 total of samples in April 2018 period, the technique used was purposive sampling, and the research instruments were anxiety questionnaire (HARS), family burden (ZBI), families' ability in caring violent behaviour patients and also spearmen rank statictic test. This research result shows that there is that the anxiety is on average level which is $48,1 \%$, the burden is also in average level which is $59,6 \%$ and the caring ability is not good which is 63,3\%. There is a relationship of anxiety with the ability of family members to treat patients with violent behavior at RSJ Prof. Dr. Soerojo Magelang. There is a family burden relationship with the ability of family members to care for patients of violent behavior in RSJ Prof. Dr. Soerojo Magelang
\end{abstract}

Key words: anxiety, family burdens, caring ability, violent behavior

\section{PENDAHULUAN}

Kesehatan jiwa menurut WHO (World Health Organization) yaitu ketika seseorang tersebut merasa sehat dan bahagia, mampu menghadapi tantangan hidup serta dapat menerima orang lain sebagaimana seharusnya serta mempunyai sikap positif terhadap diri sendiri dan orang lain. Kesehatan jiwa masih menjadi salah satu permasalahan kesehatan yang signifikan di dunia, termasuk di Indonesia. Menurut WHO (2016), terdapat sekitar 35 juta orang terkena depresi, 60 juta orang terkena bipolar, 21 juta orang terkena skizofrenia, serta 47,5 juta terkena dimensia. Jumlah penderita gangguan jiwa di Indonesia pada tahun 2013 mencapai 236 juta orang, dengan kategori gangguan jiwa ringan $6 \%$ dari populasi dan $0,17 \%$ menderita gangguan jiwa berat, $14,3 \%$ diantaranya mengalami pasung. Tercatat sebanyak $6 \%$ penduduk berusia 15-24 tahun mengalami gangguan jiwa. Dari 34 provinsi di Indonesia, Sumatera Barat merupakan peringkat ke 9 dengan jumlah gangguan jiwa sebanyak 50.608 jiwa dan prevalensi masalah skizofrenia pada urutan ke-2 sebanyak 1,9 permil. Peningkatan gangguan jiwa yang terjadi saat ini akan menimbulkan masalah baru yang disebabkan ketidakmampuan dan gejala-gejala yang ditimbulkan oleh penderita (Riskesdas, 2013). 
Dinas Kesehatan Jawa Tengah (2012), mengatakan angka kejadian penderita gangguan jiwa di Jawa Tengah berkisar antara 3.300 orang hingga 9.300 orang. Angka kejadian ini merupakan penderita yang sudah terdiagnosa. Data kejadian perilaku kekerasan pada bulan Mei-Oktober 2017 di Rumah sakit jiwa Prof. Dr. Soerojo Magelang mencapai 643 pasien. Perilaku kekerasan merupakan suatu bentuk perilaku yang bertujuan untuk melukai seseorang secara fisik maupun psikologis. Perilaku kekerasan dapat dilakukan secara verbal, diarahkan pada diri sendiri, orang lain, dan lingkungan. Perilaku kekerasan dapat terjadi dalam dua bentuk yaitu saat sedang berlangsung perilaku kekerasan atau riwayat perilaku kekerasan (Dermawan dan Rusdi, 2013).

Dampak perilaku kekerasan yang dilakukan pasien terhadap dirinya sendiri adalah dapat mencederai dirinya sendiri atau merusak lingkungannya. Bahkan dampak yang lebih ekstrim yang dapat ditimbulkan adalah kematian bagi pasien sendiri dan dampak perilaku kekerasan bagi keluarga yaitu merasa takut terhadap perilaku kekerasan pasien seperti menyerang atau mengancam orang lain dengan senjata (Nuraenah dkk, 2012). Keluarga merupakan orang terdekat dengan pasien, dimana perlu mengetahui proses munculnya perilaku kekerasan yang dialami anggota keluarganya, dan perlu memonitor perilaku pasien yang menunjukkan tanda-tanda marah, amuk, gaduh, gelisah dan agresif. Keluarga memiliki tanggung jawab untuk merawat. Pasien perilaku kekerasan membutuhkan dukungan keluarga yang mampu memberikan perawatan secara optimal. Tetapi keluarga sebagai sistem pendukung utama sering mengalami beban yang tidak ringan dalam memberikan perawatan selama pasien dirawat di rumah sakit maupun setelah kembali ke rumah (Nuraenah dkk, 2012).

Beban tersebut yaitu beban finansial dalam biaya perawatan, beban mental dalam menghadapi perilaku pasien, dan beban sosial terutama menghadapi stigma dari masyarakat tentang anggota keluarganya yang mengalami gangguan jiwa.

Dampak dari beban yang dirasakan keluarga akan mempengaruhi kemampuan keluarga dalam merawat pasien. Jika keluarga terbebani keluarga tidak mampu merawat pasien dengan baik (Suryaningrum, 2013).

Merawat pasien perilaku kekerasan menimbulkan berbagai masalah seperti gangguan psiklogis yang dapat diderita anggota keluarga merawat pasien perilaku kekerasan antara lain, stres, frustasi, kurangnya interaksi sosial, menurunya harga diri, depresi dan kecemasan. Kecemasan akan muncul pada keluarga yang salah satu anggota keluarganya sedang sakit dan memerlukan perawatan di rumah sakit (Ariani, 2014)

Kecemasan adalah ketegangan, rasa tidak aman dan kekhawatiran yang timbul karena dirasakan terjadi sesuatu yang tidak menyenangkan, tetapi sumbernya sebagian besar tidak diketahui dan berasal dari dalam (DepKes $\mathrm{RI})$.

Berdasarkan hasil pra-survey peneliti di Rumah Sakit Jiwa Prof. Dr. Soerojo Magelang pada tanggal 04 Januari 2018, wawancara pada 5 anggota keluarga yang anggota keluarganya dengan perilaku kekerasan 3 diantaranya mengeluh cemas dan mengalami beban merawat anggota keluarga dengan perilaku kekerasan.

\section{METODE PENELITIAN}

Penelitian ini menggunakan desain korelasi dengan pendekatan cross sectional yang dilakukan di Rumah Sakit Jiwa Prof. Dr. Soerojo Magelang, penelitian dimuali pada 01 April 2018 - 01 Mei 2018. Sampel pada penelitian ini adalah keluarga yang memiliki anggota keluarga dengan perilaku kekerasan sebanyak 52 responden yang diambil menggunakan teknik purposive sampling. Instrumen yang digunakan dalam penelitian ini adalah kuesioner Hamilton Anxiety Rating Score (HARS), kuesioner The Zarith Burden Interview (ZBI) dan kuesioner kemampuan anggota keluarga merawat. Analisa data menggunakan uji statistik spearman-rank dengan taraf signifikan sebesar 0,05 .

\section{HASIL DAN PEMBAHASAN}

Tabel 1 Distribusi Frekuensi Kecemasan Anggota Keluarga yang Merawat Pasien Perilaku Kekerasan di Rumah Sakit Jiwa Prof. Dr. Soerojo Magelang $(n=52)$ 


\begin{tabular}{lcc}
\hline Kecemasan & F & $\%$ \\
\hline Tidak ada kecemasan & 2 & 3,8 \\
Kecemasan ringan & 15 & 28,8 \\
Kecemasan sedang & 24 & 46,2 \\
Kecemasan berat & 11 & 21,2 \\
\hline Total & 52 & 100 \\
\hline
\end{tabular}

Berdasarkan tabel 1 diatas menunjukan bahwa dari 52 responden, kecemasan yang paling banyak ditemukan adalah kecemasan sedang yaitu sebanyak 24 responden atau $46,2 \%$.

Tabel 2 Distribusi Frekuensi Beban Keluarga Anggota Keluarga Yang Merawat Pasien Perilaku Kekerasan di Rumah Sakit Jiwa Prof. Dr. Soerojo Magelang ( $\mathrm{n}=52)$

\begin{tabular}{lcc}
\hline Beban keluarga & $\mathrm{F}$ & $\%$ \\
\hline Tidak ada beban & 2 & 3,8 \\
Beban ringan & 14 & 26,9 \\
Beban sedang & 31 & 59,6 \\
Beban berat & 5 & 9,6 \\
\hline Total & 52 & 100 \\
\hline
\end{tabular}

Berdasarkan tabel 2 dapat diketahui bahwa dari 52 responden, beban keluarga paling banyak ditemukan adalah beban keluarga sedang yaitu sebanyak 31 responden atau $59,6 \%$.

Tabel 3 Distribusi Frekuensi Kemampuan Anggota Keluarga Merawat Pasien Perilaku Kekerasan di Rumah Sakit Jiwa Prof. Dr. Soerojo Magelang $(n=52)$.

\begin{tabular}{lcc}
\hline Kemampuan Merawat & F & $\%$ \\
\hline Baik & 19 & 36,5 \\
Tidak baik & 33 & 63,5 \\
\hline Total & 52 & 100 \\
\hline
\end{tabular}

Berdasarkan tabel 3 dapat diketahui bahwa dari 52 responden, kecenderungan memiliki kemampuan merawat tidak baik yaitu sebanyak 33 responden atau $63,5 \%$

Tabel 4 Hubungan Kecemasan dengan Kemampuan Anggota Keluarga Merawat Pasien Perilaku Kekerasan di Rumah Sakit Jiwa Prof. Dr. Soerojo Magelang $(\mathrm{n}=52)$

\begin{tabular}{|c|c|c|c|c|c|}
\hline \multirow{3}{*}{ Kecemasan } & \multicolumn{2}{|c|}{$\begin{array}{c}\text { Kemampuan } \\
\text { Merawat }\end{array}$} & \multirow{2}{*}{$\sum$} & \multirow{3}{*}{$p$} & \multirow{3}{*}{$\mathrm{CC}$} \\
\hline & $\begin{array}{l}\text { Tidak } \\
\text { Baik }\end{array}$ & Baik & & & \\
\hline & $\mathrm{F}(\%)$ & $\mathrm{F}(\%)$ & $\mathrm{F}$ & & \\
\hline $\begin{array}{l}\text { Tidak ada } \\
\text { kecemasan }\end{array}$ & $1(50,0)$ & $1(50,0)$ & 2 & & \\
\hline $\begin{array}{l}\text { Kecemasan } \\
\text { ringan }\end{array}$ & $4(26,7)$ & $11(73,3)$ & 15 & & \\
\hline $\begin{array}{l}\text { Kecemasan } \\
\text { sedang }\end{array}$ & $21(87,5)$ & $3(12)$ & 25 & $\begin{array}{c}0,01 \\
7\end{array}$ & 0,330 \\
\hline $\begin{array}{l}\text { Kecemasan } \\
\text { berat }\end{array}$ & $7(58,3)$ & $4(36,4)$ & 12 & & \\
\hline Total & $33(63,5)$ & $19(36,5)$ & 52 & & \\
\hline
\end{tabular}

Berdasarkan data tabel 4.3 di atas diketahui bahwa dari 52 responden dengan kemampuan anggota keluarga merawat pasien perilaku kekerasan dengan kemampuan tidak baik mayoritas memiliki kecemasan sedang sebanyak 21 responden $(87,5 \%)$.

Hasil uji statistik menggunakan uji spearman rank menunjukan bahwa $p$ value 0,017 ( $p$ value $\leq 0,05$ ) yang artinya ada hubungan kecemasan dengan kemampuan anggota keluarga merawat pasien perilaku kekerasan di rumah sakit jiwa Prof. Dr. Soerojo Magelang, dengan nilai -0.330 , yang artinya berada pada tingkat kategori lemah, dengan arah hubungan negatif artinya semakin tinggi kecemasan, maka kemampuan merawat semakin menurun.

Tabel 5 Hubungan Beban Keluarga dengan Kemampuan Anggota Keluarga Merawat Pasien Perilaku Kekerasan di Rumah Sakit Jiwa Prof. Dr. Soerojo Magelang $(\mathrm{n}=52)$

\begin{tabular}{|c|c|c|c|c|c|}
\hline \multirow{3}{*}{ Kecemasan } & \multicolumn{2}{|c|}{$\begin{array}{c}\text { Kemampuan } \\
\text { Merawat }\end{array}$} & \multirow{2}{*}{$\sum$} & \multirow{3}{*}{$p$} & \multirow{3}{*}{$\mathrm{CC}$} \\
\hline & $\begin{array}{l}\text { Tidak } \\
\text { Baik }\end{array}$ & Baik & & & \\
\hline & $\mathrm{F}(\%)$ & $\mathrm{F}(\%)$ & $\mathrm{F}$ & & \\
\hline $\begin{array}{l}\text { Tidak ada } \\
\text { beban }\end{array}$ & $0(0)$ & $2(100)$ & 2 & \multirow{2}{*}{$\begin{array}{c}0,02 \\
8\end{array}$} & - \\
\hline $\begin{array}{l}\text { Beban } \\
\text { ringan }\end{array}$ & $6(42,9)$ & $8(57,1)$ & 14 & & 0,305 \\
\hline
\end{tabular}




\begin{tabular}{llll}
\hline $\begin{array}{l}\text { Beban } \\
\text { sedang }\end{array}$ & $24(77,4)$ & $7(22,6)$ & 31 \\
$\begin{array}{l}\text { Beban berat } \\
\text { Total }\end{array}$ & $33(60,0)$ & $2(40,0)$ & 5 \\
& $33(63,5)$ & $19(36,5)$ & 52 \\
\hline
\end{tabular}

Berdasarkan tabel 4.5 dapat diketahui bahwa dari 52 responden dengan kemampuan anggota keluarga merawat pasien perilaku kekerasan dengan kemampuan tidak baik mayoritas memiliki beban sedang sebanyak 24 responden $(77,4 \%)$.

Hasil uji statistik menggunakan uji spearman rank menunjukan bahwa $p$ value 0,028 ( $p$ value $\leq 0,05$ ) yaitu ada hubungan beban keluarga dengan kemampuan anggota keluarga merawat pasien perilaku kekerasan di rumah sakit jiwa Prof. Dr. Soerojo Magelang, dengan nilai -0.305 , yang artinya berada pada tingkat kategori lemah, dengan arah hubungan negatif artinya semakin tinggi beban keluarga, maka kemampuan merawat semakin menurun.

\section{PEMBAHASAN \\ Kecemasan}

Hasil penelitian yang dilakukan pada 52 responden ditemukan empat kategori kecemasan. Tidak ada kecemasan sebanyak 2 responden $(3,8 \%)$ kecemasan berat sebanyak 11 responden $(21,2 \%)$, kecemasan ringan sebanyak 15 responden $(28,8 \%)$ dan kecemasan sedang sebanyak 24 responden (46,2\%).

Menurut Yusuf dkk (2015) kecemasan merupakan suatu perasan tidak santai yang samar-samar karena ketidaknyamanan atau rasa takut yang disertai suatu respon (penyebab tidak spesifik atau tidak diketahui oleh individu). Kecemasan sedang memungkinkan individu berfokus pada hal yang penting dan mempersempit lapang persepsi. Individu melihat, mendengar dan menyerap lebih sedikit. Individu menjadi tidak perhatian yang selektif namun dapat melakukan jika diarahkan (Arifiani dkk, 2017). Namun cemas juga dibutuhkan individu dalam tingkat ringan sebagai alarm terhadap stimulus.

Faktor-faktor yang mempengaruhi kecemasan sedang pada penelitian ini yaitu minimnya pengetahuan responden mengenai sehat sakit sehingga muncul perasaan cemas. Hal tersebut juga diteliti oleh Mubarok (2006) bahwa tingkat pengetahuan keluarga tentang sehat sakit mempengaruhi perilaku dalam menyelesaikan masalah kesehatan keluarga semakin tinggi pengetahuan keluarga maka keluarga tersebut dapat menyelesaikan masalah kesehatannya, menurut Ulfah (2010) apabila keluarga memiliki pengetahuan tinggi tentang gangguan jiwa dan cara merawatnya, maka keluarga mampu menyelesaikan masalah tersebut namun banyak keluarga pada penelitian ini yang memiliki pengetahuan rendah yang menyebabkan keluarga sulit menyelesaikan masalah tersebut dan menjadi ancaman sehingga muncul kecemasan.

\section{Beban Keluarga}

Hasil penelitian yang dilakukan pada 52 responden ditemukan sebanyak 2 responden $(3,8 \%)$ tidak memiliki beban, beban berat sebanyak $5(9,6 \%)$, beban ringan sebanyak 14 $(26,9 \%)$, dan sisanya 31 responden $(59,6 \%)$ mengalami beban keluarga sedang.

Hasil temuan peneliti $59,6 \%$ responden memiliki beban sedang dikarenakan responden merasa malu anggota keluarganya ada yang mengalami gangguan jiwa, asumsi peneliti sejalan dengan penelitian Istiana (2015) yang mengatakan 100 responden 52 diantaranya mengalami beban sedang, karena sebagian besar keluarga merasa malu dan putus asa dalam merawat pasien dengan gangguan kejiwaan.

Beban keluarga dapat diartikan sebagai stres atau efek dari pasien gangguan jiwa terhadap keluarga. Beban keluarga adalah tingkat pengalaman distress keluarga sebagai efek dari pasien gangguan jiwa terhadap keluarganya. Kondisi ini dapat menyebabkan meningkatnya stress emosional dan ekonomi dari keluarga. Ada beberapa jenis beban salah satunya adalah beban subjektif, yaitu beban yang berhubungan dengan kehilangan, takut, merasa bersalah, marah, malu dan perasaan negatif lainnya yang dialami oleh keluarga pada penelitian ini sebagai respon terhadap anggota keluarga yang mengalami gangguan jiwa.

Menurut peneliti, responden yang megalami beban sedang menggambarkan bahwa anggota keluarga mengalami gangguan kesehatan khususnya kesehatan mental akan 
meningkatkan beban subjektif bagi anggota keluarga yang merawat pasien, anggota keluarga merasa pasien meminta bantuan secara berlebih, merasa cemas dan malu. Hal ini didukung oleh penelitian Mubin (2008) menyatakan bahwa keluarga dengan penderita gangguan jiwa sering mengalami luka fisik akibat perilaku kekerasan pasien, ketika pasien mengamuk atau mendapatkan perlakuan tidak baik dari tetangga, keluarga juga akan merasakan beban subjektif seperti muncul rasa khawatir, cemas, pesimis dan malu.

\section{Kemampuan Merawat}

Hasil penelitian yang dilakukan pada 52 responden ditemukan $33(63,5 \%)$ responden mengalami kemampuan merawat anggota perilaku kekerasan tidak baik, dan sisanya 19 $(36,5 \%)$ responden mengalami kemampuan baik.

Menurut Craven (2000) dalam Hasmila (2009) mengatakan Perilaku manusia yang sangat kompleks dapat dibagi menjadi 3 domain yaitu kognitif, afektif dan psikomotor, selanjutnya ketiga domain tersebut lebih dikenal sebagai pengetahuan, sikap dan praktek. Praktek atau psikomotor merujuk pada pergerakan muskuler yang merupakan hasil dari koordinasi pengetahuan dan menunjukkan penguasaan terhadap suatu tugas atau ketrampilan. Hasil temuan dalam penelitian ini, kemampuan merawat itu adalah pengetahuan, sikap dan praktek oleh karena itu kemampuan anggota keluarga merawat pasien perilaku kekerasan mengalami kemampuan tidak baik karena sikap responden mengalami cemas, pengetahuan yang rendah menegenai penyakit yang diderita anggota keluarganya dan merasa terbebani.

Hubungan kecemasan dengan kemampuan anggota keluarga merawat pasien perilaku kekerasan.

Hasil analisa bivariat menunjukan bahwa ada hubungan antara kecemasan dengan kemampuan anggota keluarga merawat pasien perilaku kekerasan di Rumah Sakit Jiwa Prof. Dr. Soerojo Magelang menunjukkan bahwa nilai uji statistik $p$ antara kecemasan keluarga dengan kemampuan anggota keluarga merawat yaitu 0,017 dan $\alpha \leq 0,05$ maka terdapat hubungan antara kecemasan dengan kemampuan anggota keluarga merawat pasien perilaku kekerasan dengan nilai arah korelasi sebesar (r) -0.330.

Berdasarkan hasil yang diperoleh dari penelitian, didapatkan sebesar 77,4\% responden mengalami kecemasan sedang dengan kemampuan merawat tidak baik. Peneliti berpendapat bahwa hal ini dipicu karena merawat pasien perilaku kekerasan dengan tingkat pengetahuan yang terbatas sehingga kecemasan yang dirasakan sedang menyebabkan kemampuan merawat tidak baik. Penelitian ini didukung oleh penelitian Sitinjak (2016) yang mengatakan hampir seluruh responden yaitu 27 responden $(70,73 \%)$ merasakan kecemasan yang sedang dalam merawat pasien hal ini karena rendahnya pengetahuan mengenai penyakit yang diderita anggota keluarga. Penelitian ini sejalan dengan penelitian yang dilakukan Ulfah (2010) apabila pengetahuan keluarga tentang gangguan jiwa kurang, maka keluarga semakin khawatir terhadap keadaan anggota keluarganya, hal ini menyebabkan keluarga menggunakan mekanisme koping yang maladaptif sehingga keluarga akan semakin cemas dan kemampuan keluarga merawat semakin menurun.

\section{Hubungan beban keluarga dengan kemampuan anggota keluarga merawat pasien perilaku kekerasan}

Hasil analisa bivariat menunjukan bahwa nilai $p$ antara beban keluarga dengan kemampuan anggota keluarga merawat pasien perilaku kekerasan di rumah sakit jiwa Prof. Dr. Soerojo Magelang yaitu 0,028 dan $\alpha \leq 0,05$ menyatakan bahwa terdapat hubungan beban keluarga dengan kemampuan anggota keluarga merawat pasien perilaku kekerasan di rumah sakit jiwa Prof. Dr. Soerojo Magelang dengan nilai arah korelasi (r) sebesar -0.305, dengan arah korelasi negatif artinya semakin besar nilai suatu variabel akan semakin kecil nilai variabel yang lain, dari hasil ini menjelaskan bahwa beban sedang akan mengalami kemampuan merawat tidak baik.

Berdasarkan hasil yang diperoleh dari penelitian, didapatkan $77,4 \%$ responden mengalami beban sedang dengan kemampuan merawat tidak baik. Menurut asumsi peneliti, responden yang megalami beban sedang pada 
penelitian ini menggambarkan bahwa ketika anggota keluarga mengalami gangguan kesehatan khususnya kesehatan mental akan meningkatkan beban bagi anggota keluarga yang merawat pasien, baik secara psikologis, sosial dan finansial sehingga kemampuan anggota keluarga dalam merawat mengalami penurunan. Menurut teori yang dijelaskan Damayanti (2012) beban finansial termasuk beban objektif. Responden dalam hal ini mengalami beban secara finansial karena biaya perawatan yang tidak sedikit ditambah biaya transportasi dan pendapatan keluarga yang rendah sehingga kemampuan dalam merawat pasien tidak baik. Hal ini didukung oleh penelitian Istiana (2015) berpendapat biaya perawatan yang tinggi menyebabkan beban dalam merawat pasien. Selain itu pendapatan keluarga yang rendah berpengaruh terhadap kondisi kehidupan, antara lain pemenuhan kebutuhan nutrisi yang tidak adekuat dan pemenuhan kebutuhan perawatan untuk anggota keluarga.

\section{KESIMPULAN}

Responden yang mengalami kecemasan sedang sebanyak $24(46,2 \%)$, beban sedang sebanyak $31(59,6 \%)$ dan kemampuan merawat tidak baik sebanyak 33 (63,3\%). Ada hubungan kecemasan dengan kemampuan anggota keluarga merawat pasien perilaku kekerasan di Rumah Sakit Jiwa Prof. Dr. Soerojo Magelang dengan $p$ value $=0,017(p<\alpha(0,05)) . \&$ ada hubungan beban keluarga dengan kemampuan anggota keluarga merawat pasien perilaku kekerasan di Rumah Sakit Jiwa Prof. Dr. Soerojo Magelang dengan $p$ value $=0,028(p<\alpha(0,05))$.

\section{SARAN}

Bagi peneliti selanjutnya sebaiknya dilakukan penelitian yang berbeda diharapkan dapat meneliti karakteristik pada masing-masing variabel yang dapat mempengaruhi kemampuan merawat seperti usia, jenis kelamin, dan tingkat pendidikan.

\section{DAFTAR PUSTAKA}

Arifiani dkk. 2017. Jurnal Keperawatan: Gambaran Tingkat Kecemasan Keluarga Pasien Skrizofrenia. 1 (1): 14-23.
Ariani Dwi. 2014. Jurnal KesMaDaSka: Hubungan Kecemasan dengan Strategi Koping pada Anggota Keluarga dengan Riwayat Perilaku Kekerasan di Wilayah Surakarta.

Damaiyanti, M dan Iskandar. 2014. Asuhan Keperawatan Jiwa. Edisi II. PT Refika Aditama, Bandung.

Damayanti dkk, 2012. Pengaruh Family Psychoeducation Islamic Therapy Terhadap beban dan Kemampuan Keluarga Merawat Klien Gangguan Jiwa.

Dermawan, D. \& Rusdi. (2013). Keperawatan jiwa: konsep dan kerangka kerja asuhan keperawatan jiwa. Yogyakarta : Gosyen Publishing.

Depkes.

2012.

http://www.depkes.go.id/folder/v iew/01/structure-publikasipusdatin-profil-kesehatan.html. Diakses Oktober 2007

Depkes RI. (2010). Pengertian Gangguan Jiwa. http://www.depkes.co.id.

Dinkes Jawa Tengah. 2010. Profil kesehatan Jawa Tengah. Jawa Tengah. http://www.dinkesjatengprov.go.i d/ Oktober 2017

Nurjanah, Fifin Puspa. 2017. Hubungan Konsep Keluarga Dan Penerimaan Masyarakat Dengan Kekambuhan Penderita Gangguan Jiwa Di Desa Karangsari Kecamatan Adipala Kabupaten Cilacap Tahun 2017.

Hasmila, S. 2009. Tesis: Pengaruh Family Psycoeducation Therapy Terhadap Beban dan Kemampuan 
Keluarga dalam Merawat Klien Pasung di Kabupaten Bireuen NAD.

Suryaningrum, S dan I.Y Wardani. 2013. Jurnal Keperawatan: Hubungan antara Beban Keluarga dengan Kemampuan Keluarga Merawat Pasien Perilaku Kekerasan di Poliklinik Rumah Sakit Marzoeki Mahdi Bogor. 1 (2): 148-155.
Ulfah. 2010. Faktor-Faktor Yang Berhubungan Dengan Kecemasan Keluarga Pada Klien Halusinasi Di Badan Pengelola Rumah Sakit Dadi Makassar. Skripsi, UIN Alauddin Makassar.

Who. 2016. Prevalensi Gangguan Jiwa. Departemen Kesehatan R.I. Direktorat Jendral Pelayanan Medik 